\title{
Al Ghazāli between Philosophy and Sufism
}

\section{Yasin Ceylan}

Al Ghazāli embarked on his investigation of four different schools of thought that were influential in his time-Bātinism, theology, philosophy, and Sufism 1 -in order to find truth in them. The first three did not satisfy him, while Sufism provided him the truth for which he had been searching. ${ }^{2}$ There have always been notable Sufis of varied backgrounds throughout the history of Islamic thought. Whereas most of them received the traditional education, some had so much interest in logic and philosophy that they pursued these fields in depth. However, none of them penetrated into these sciences as far as al Ghazālì, who acquired an intimate knowledge of both philosophy and theology.

Of all of the theologians who penetrated philosophy so deeply, none but al Ghazāti managed to escape its harmful impact and, after mastering it, refute it. Many previous intellectuals had attacked philosophy from the viewpoint of religious or other convictions, but none were as original and influential as al Ghazāti. Their arguments against philosophy were not taken seriously, for they were unable to use philosophical terminology properly and could hardly grasp the meanings of the various complicated and abstract arguments.

However, al Ghazāti's case is completely different. His rejection of philosophy and his status as the author of such philosophical works as The Intentions of the Philosophers and The Inconsistency of the Philosophers, which rank high in the Islamic version of Peripatetic philosophy, are milestones. The contents of these two books have been subjected to frequent distortion by various factions: Theologians hailed these works as representing the victory of religious faith over philosophical thinking, while intellectuals inclined toward philosophy considered them to be examples of sheer antagonism toward philosophy in general. However, this case is not so trivial that it can be exploited by a scholar-jurist or so shallow and lacking in depth that it can be considered "a prejudicial act against philosophy" by a mediocre philosopher.

Al Ghazāli himself discloses why he was frustrated by philosophy in his quest for truth and why he chose to adopt Sufism instead. His account may be summed up as follows: His disillusionment with philosophy was derived from its destructive effect on the fundamentals of religion, while his attraction to Sufism was rooted in the fact that ethical refinement and the purification of the soul were necessary conditions in this discipline. 
Let us now discuss al Ghazāli’s first allegation: Does philosophy really shake one's religious convictions or not? When the intellectual thought of great philosophers-including al Ghazāli-is examined, it will be observed that they usually start thinking differently and systematically after they become skeptical about their beliefs and presuppositions. Skeptical thinking leads to cautious attitudes toward, and loss of confidence in, all of the values acquired through one's family and society. The resulting abandonment of superstitions and reactionary traditions is a necessary preparatory stage for any intellectual who wants to be consistent and productive in his/her reasoning. However, this skeptical approach destabilizes not only groundless beliefs and prejudices, but also those universal rules at the bottom of moral action and those dogmas necessary for a communal coexistence. While it works constructively in some areas, it may also be destructive in others.

Those who define the philosophical approach as critical thinking and further refine the latter as treating matters skeptically must accept this undesirable aspect of philosophy. Nevertheless, it is known that Plato and Aristotle fought against the contention that "to philosophize is to doubt" in their attempts to refute the Sophists and dialecticians who upheld this thesis. ${ }^{4}$ Muslim philosophers were acquainted with the arguments of these two Greek philosophers when they took over the Peripatetic philosophy from the late Hellenistic philosophers. They even contributed to this endeavor by formulating new arguments against the proponents of skepticism.

Given this situation, what could have led al Ghazālı to work against Muslim philosophers and the philosophy that they developed from the destructive aspect of skepticism? The assumption that he was unable to fully understand the various philosophical issues or that he misunderstood the philosophers' intentions is unacceptable, for the two books mentioned above prove that he had a comprehensive and full grasp of the philosophical thought current at that time. Rather, it appears that he did so to counter the dogmatic nature of their philosophical speculations as well as their interpretation of the fundamentals of religion in terms of philosophical concepts. The danger that he saw in such an approach was that these philosophical systems of thought appeared as alternative sets of beliefs to religion. As a philosophical religion is unacceptable for the masses and impractical for instruction, it can only be detrimental to the existing faith held by the people and their respect for the related institutions. This kind of philosophy embarrassed al Ghazālı and led him to make his famous statement that such philosophy should not be sought after or studied.'

To illustrate the two negative aspects of Peripatetic philosophy, the following examples can be given. Muslim philosophers who accepted the theory of emanation, which was received from the Greek philosopher Plotinus, represented it as a substitute for the Qur'anic account of the creation of the world. ${ }^{6}$ The Aristotelian theory of motion, which leads to the eternity of matter as the locus of movement, was adopted by Muslim philosophers and adduced as a convincing demonstration for the eternity of the world.' 
However, this theory was a clear contradiction of the Qur'anic statement that God created the world out of nothing. Plato's doctrine of the soul after death, as expounded in Timaeus, had such an impact on the philosophies of al Fārābī and Ibn Sinā' that they considered it to be a more probable account than the Qur'anic version. ${ }^{8}$ As regards the second aspect, one has only to note the painstaking effort of Ibn Sinā' and al Fārābī to provide a philosophical explanation for prophecy, ${ }^{9}$ their identification of the Plotinian "ten intelligences" with the archangels of the Qur'an, ${ }^{10}$ and Ibn Rushd's development and application of an exegetical method to the verses of the Qur'an to substantiate Aristotelian philosophy."

During the ninth, tenth, and eleventh centuries, all streams of philosophic thought and speculation acquired a negative status because of these two factors. Thus, those who sought or who had already acquired a harmony between faith and practice were apprehensive about philosophy and philosophers and held that its adverse effects outnumbered its benefits. As a matter of fact, these two aspects were not unique to Muslim philosophers but were characteristic of all medieval thought and intellectuals. Muslim philosophers could not really avoid them, for it was an age of faith and religion was dominant everywhere. If a philosopher did not deal with the "problem" of religion, he would be accused of avoiding the real issue.

When philosophy was introduced in this fashion during the twelfth century, it was impossible for al Ghazăli to expect that it could help him satisfy his aspiration to become a perfect person (al insān al kämil). Thus, his identification of such a philosophy with the destructive consequences of skepticism was quite natural. In addition, it was impossible for him to familiarize himself with other non-Peripatetic schools of philosophy, for there was neither enough time nor enough philosophical literature in Arabic and Persian available to him. Moreover, the skeptical approach, which al Ghazāli regards as the crux of philosophical thought and which shakes the foundations of religion, should not be the aim of philosophy. A philosopher uses the techniques of skepticism in his search for truth. Otherwise, how can he differentiate between truth and falsehood? Even a believer uses these techniques to a certain degree: Whereas reference is made to divine authority in major issues, he/she might question some of the rulings of the religious (or other) authorities in minor matters if they are not understandable.

It is normal for a philosopher to doubt the truth of received beliefs, as it is his/her intention to go beyond them in order to discover more comprehensive truths. What is sought is not the annihilation of these beliefs, but rather their replacement with those that are less restrictive and more universal. If this attempt fails, assent is either given to the prevailing beliefs or judgment is suspended. If the philosopher is unable to provide better substitutes and thus is forced to agree with the prevailing beliefs, he/she is morally obliged to disclose the unsatisfactory aspects of these 
substitutes, just as he/she did when handling the originals. Hence, a philosopher's mission is not to destroy beliefs but to establish them and to destroy those aspects of the belief structure that are mistakenly held to be essential so that they can be replaced by those that are truly essential. In so doing, the individual no longer has to remain "small" due to mediocre beliefs, but can become "great" through universal ones.

One important requirement of these universal beliefs is that they should not be pure abstract expressions devoid of any real effect on human life. If they are not related closely to human reality and behavior regulation, they are incomplete and undeserving of the intellectual effort needed to study them. However, if a philosopher has failed to become a perfect person through philosophical training, he/she creates a case for al Ghazālì, or for anyone else who searches for truth and guidance, to make allegations against philosophy and its exponents. That is why al Ghazāli, when explaining his choice between philosophy and Sufism, emphasized the practical aspect: the refinement of action and behavior. He stated openly that he did not see such a result in the case of the jurists (fuqahä') or the philosophers. This was not an easy job, for it required the purification of one's soul and activities, of which it is the agent. In a sense, a change of character is a prerequisite for one who is striving to become a perfect person. He was convinced that one could not reach this stage via theoretical knowledge alone, for he believed that no knowledge could assume the status of human reality until it was reflected in one's actions.

$\mathrm{Al}$ Ghazāli mentions three fundamental features related to his mystical experience: a) the purification of the soul from those evils and worldly desires that hinder moral perfection; b) those spiritual dispositions or explorations that occur after the process of purification reaches the level of maturity (described as extraordinary intellectual intuitions) $;{ }^{12}$ and c) that these dispositions are not explicable through reason..$^{13}$

To evaluate these in philosophical terms, one can interpret the first as the full application of universal moral norms to every manifestation of spiritual affections and all acts governed by them. An inevitable condition of this fulfillment is that moral norms should be divested of all restrictions and conditions that might disturb their two conspicuous qualities: necessity and universality. In a sense, this is the perfection of practical reason. The spiritual dispositions or explorations (as al Ghazāli calls them) that result from the ascension of practical reason and that are harnessed through discipline cannot be understood by theoretical reason and therefore are not proper subjects for such an undertaking.

To explain this difficulty, al Ghazālı maintains that just as sensibility falls short of intellection, so intellect itself falls short of grasping the nature of mystical experience. Thus, in his opinion, mystical experience belongs to a different category of knowledge and should not be put aside only 
because it cannot be handled by reason. ${ }^{14}$ However, if reason is incapable of assessing the truth-value of mystical experience, the only other possible criterion is to experience the mystical dispositions themselves. As such an undertaking is not convenient for a curious researcher, the question as to the nature of this experience will remain open. One effective manner of description is poetry, but poetry can hardly be analyzed fully by our faculty of cognition. The message the poet wants to convey is somehow given and the reader receives it, but this interaction cannot possibly be put into the propositions of theoretical reason, which can only be rendered in prose.

In view of al Ghazāli's account of mystical experience, one is driven to the conclusion that the human mind has the potential to transcend all ostensible values of moral actions when moral maxims are internalized in their absolute sense and independent of moral acts. This poses a parallel case to the pure ideas of theoretical reason, which are the basis of metaphysics and are not applicable to empirical knowledge. In both cases, however, there is always the danger of misusing them, which happens quite often. When pure ideas are misused, the resulting paralogisms mar the reliability of theoretical reason. When the absolute maxims of practical reason are misused, awkward expressions and eccentric actions are generated.

Examples of these can be seen in some of the obscure expressions and abnormal acts of mystics. Though they are the highest levels to which any human being can aspire, they are highly sensitive and susceptible to misuse. Mistakes committed at these levels cause great confusion in the minds and attitudes of individuals and can hardly be amended. Such mistakes are motivated mainly by the desire of the metaphysician and the mystic to communicate their speculations or experiences to others and thus make them available to all. Those involved in such attempts, however, find that frustration is inevitable, for there is no appropriate vocabulary for such a unique knowledge and experience. Words borrowed from other fields can never express these reflections of the soul and will only cause ambiguity and confusion among the people. Thus, the use of pure ideas and the absolute maxims of reason must be confined to the individual only and, as a result, remain subjective. Any attempt to objectify them is doomed to failure.

As regards the question of whether precedence should be given to practical reason (morality) or to theoretical reason (cognition) in the course of becoming a perfect person, it is unfair to emphasize one at the expense of the other. A philosopher who has not refined his/her moral actions is far from perfection, and a mystic who has not undergone a theoretical training will never appreciate the role of understanding in his/her struggle for moral perfection. Thus, the perfect person is one who has perfected himself/herself in both realms (aesthetic perfection can also be added here). Al Ghazāli’s importance becomes more obvious when his training in both fields is taken into account. 


\section{Endnotes}

1. Bätinism, a term derived from the Arabic term hätin (lit. "internal"), was a Muslim school of thought that flourished during the ninth to eleventh centuries. Its adherents emphasized the esoteric meaning of the Qur'anic verses. In opposition to this line of thought, another school was founded by Ibn Hazm (993-1064) of Spain. This school emphasized the literal meaning of the Qur'anic verses and thus was referred to as the Zãhini school of thought (zähir means "external"). For further information, refer to Ignaz Goldziher's two works: Streitschrift de Gazali gegen die Batiniyya-Sekte (Leiden: 1916) and Die Zahiriten, ihr Lehrsystem und ihre Geschichte (Leipzig: 1884). Sufism is the name used for Islamic mysticism. Although it has common features with mysticism in general, it is distinguished by certain characteristics that are mainly Islamic. See Reynold A. Nicholson, The Mystics of Islam (London: Routledge and Paul, 1963).

2. al Ghazālî, ul Munqidh min al Daläl (Beirut: 1959), 43-44.

3. W. Montgomery Watt (trans.), Faith and Practice of Al Ghazali (London: G. Allen and Unwin, 1963), 55. This consists of translations of al Ghazăli’s Munqidh and Bidāyat al Hidāyah.

4. See Aristotle's Sophistical Refutations and Plato's Sophist and Gorgias.

5. al Ghazā̄î, al Munqidh, 27-28, and Tahäfut al Falāsifah (Cairo: 1957), 268.

6. R. Walzer (trans. and comm.), al-Farabi on the Perfect State (Oxford: Clarendon Press, 1985), 89-101. See his commentary on pp. 352-55.

7. 'Abd al Raḥmān al Badawì, al Aflaṭūniyah al Muhdathah 'indã al 'Arah (Cairo: $1955), 38$.

8. Walzer, The Perfect City, 259-77.

9. Ibid., 223-25. See also Ibn Sinā's treatise on this issue: Fì Ithbāt al Nubüwah (Beirut: 1968).

10. Walzer, The Perfect City, 39.

11. Ibn Rushd, Kitāb Faṣl al Maqāl, trans. George Hourani (London: 1967), 44-63. See also Olivier Leaman, Averroes and His Philosophy (Oxford: Clarendon Press, 1988), 144.

12. 'Abd al Raḥmān Dimashqīyah, Abū Ḥamìd al Ghazāli wa Tașawwuf (Riyadh: 1986), 182-92.

13. al Ghazāir, al Munqidh, 50.

14. For further information, see Nicholson, Mystics of Islam, 148-68.

Yasin Ceylan

Department of Philosophy

Middle East Technical University

Ankara, Turkey 